\title{
EFFECTS OF SQUARE-MESH CODEND ON THE BENTHIC BY-CATCH FOR THE BEAM TRAWL FISHERIES OF VEINED RAPA WHELK, RAPANA VENOSA
}

\author{
Ahmet R. ERYAŞAR* \\ Recep Tayyip Erdogan University, Vocational School of Technical Sciences, Underwater Technology Program, \\ Rize, Turkey
}

Eryaşar A.R. 2018. Effects of square-mesh codend on the benthic by-catch for the beam trawl fisheries of veined rapa whelk, Rapana venosa. Acta Ichthyol. Piscat. 48 (2): 173-181.

\begin{abstract}
Background. The beam trawl fisheries of veined rapa whelk, Rapana venosa (Valenciennes, 1846), cause small benthic organisms to be captured and also damage the other species living on the seafloor. To solve this problem, a proper modification that minimise the by-catch should be designed and put into practice. This study aims to compare $72 \mathrm{~mm}$ commercial diamond-mesh codend with $72 \mathrm{~mm}$ square-mesh codend to reduce the benthic bycatch in this fishery.
\end{abstract}

Materials and methods. Totally 15 hauls were carried out in south-eastern Black Sea Region within 10-14 August 2017. A commercial diamond-mesh and square-mesh beam trawls were towed simultaneously behind a commercial fishing vessel to compare the by-catch compositions. Paired $t$-test was used to compare the catch amount of two codends based on species. GLMM (Generalised Linear Mixed Models) was used to compare the length of captured veined rapa whelk, mussel, and crab species.

Results. There was a 77-percentage-point reduction in the mean number of the captured individuals as by-catch in square-mesh codend when compared with commercial diamond-mesh codend and this difference was found statistically significant $(P<0.05)$. A total of 17 species was captured as by-catch in both codends. Comparing to diamond-mesh codend, the catch amount of the 13 by-catch species had decreased in square-mesh codend.

Conclusions. In conclusion, the square-mesh codend was found successful in decreasing the by-catch amount of many benthic species except for flatfish species and large crabs. In addition to this, the veined rapa whelk amount fell by half and this means a 25-percentage-point profit decrease for fishermen.

Keywords: beam trawl, veined rapa whelk, Mollusca, benthic by-catch, square-mesh codend

\section{INTRODUCTION}

The veined rapa whelk, Rapana venosa (Valenciennes, 1846), is one of the most important commercial species in south-eastern Black Sea region (Kideys et al. 2007) and it constitutes an important source of income for artisanal fishery in the region although its negative impacts on the benthic ecosystem have been observed (Bilecik 1990, Sağlam et al. 2011). Among the Black Sea countries, the veined rapa whelk fisheries is carried out by Bulgaria, Turkey, Georgia, Ukraine, and Russia; however, the largest yields are achieved in the eastern Black Sea Region (Anonymous 2016c). In the veined rapa whelk fishery, traditional beam trawl method (locally known as algarna) is preferred because of its high efficiency (Altınağaç et al. 2004). Algarna is operated with beam trawl technique (Kaykaç et al. 2014) but it is smaller than beam trawl that is normally used. For this fishery, target species is only the veined rapa whelk and other species like fish and crab are thrown back into the sea as dead or alive and small ones like bivalves are packed with the target species without any elimination (Eryaşar et al. 2018).
The incidental capture of non-target marine animals during fishing is commonly referred to as a by-catch. By-catches can cause a conservation problem when endangered species are affected or when the level of capture is not sustainable for the non-target animals (Hall et al. 2000). It is also one of the most important problems for fisheries management since it is considered a waste of marine resources, a source of uncertainty for fisheries scientists and decision-makers (Hall et al. 2000, Tsagarakis et al. 2014).

Beam trawls are also used in the rapa whelk fishery in Bulgaria coasts (western Black Sea) and by-catch of the veined rapa whelk beam trawl fisheries have estimated as $7.5 \%$ for this region (Kelleher 2005, Anonymous 2016b). The negative effects of beam trawls on mussel beds have been reported by Konsulova et al. (2001). Similar findings were reported by Eryaşar et al. (2018) for the south-eastern Black Sea. Eryaşar et al. (2018) investigated the by-catch composition of the veined rapa whelk beam trawl fisheries and they showed that 28 by-catch species 
were determined in total and $11.4 \%$ of catch (in terms of number) was composed of by-catch species. In addition, striped venus clam (Chamelea gallina) and blood cockle (Anadara kagoshimensis) belonging to Bivalvia class were determined as the most captured by-catch species and also besides these species, a large number of crab and flatfish species had been caught as non-target organisms. Eryaşar et al. (2018) also reported that beam trawls have a serious impact, especially on the bivalve species due to high rate of juveniles which they are taken from the environment without spawning at least once.

The studies carried out to increase the selectivity of bottom trawl net in the Mediterranean Sea showed that square-mesh codend or panels give more chance to juveniles of most species to escape when compared with diamond-mesh codends (Sala et al. 2008, Ateş et al. 2010, Tokaç et al. 2010, Eryaşar and Özbilgin 2015). Underwater observations carried out by Robertson and Stewart (1988) for bottom trawl codends showed that the mesh has a tendency to close, depending upon increasing catch amount in diamond-mesh codend but in squaremesh codend, the mesh stayed open during the tow. Fonteyne and Polet (2002) showed that square-mesh windows inserted in the belly just in front of the codend significantly reduced the by-catch amount of the majority of benthic species in the flatfish beam trawl fisheries.

Although limited studies about the catch composition of the veined rapa whelk beam trawl fisheries have been carried out (Eryaşar et al. 2018, Sağlam et al. unpublished*), there has not found any study on by-catch reduction for this fishery. However, when considering the success of square-mesh codend and/or panels on reducing discard rate of many species for bottom towed gears, square-mesh codend was aimed to test for reducing the by-catch amount in the veined rapa whelk beam trawl fisheries. For this purpose, square-mesh codend was compared simultaneously with commercial codend to reduce the by-catch and the negative impact of this fishing gear on benthic species.

\section{MATERIALS AND METHODS}

Two beam trawls had been towed simultaneously by a vessel to compare the by-catch compositions of two types of codend. A commercial fisheries vessel was chartered for hauls and beam trawls of fishermen were used. Hauls were carried out between 10 and 14 August 2017 in the commercial fishing ground of Rize in southeastern Black Sea (Fig.1), at depths between 9.8 and 17.3 m. 15 hauls were performed in total and haul durations differed between 20 to $23 \mathrm{~min}$. Haul speed ranged from 1.5 to 2.4 knots. Two hauls were cancelled because of the entanglement of beam trawls.

The beam trawls used in the hauls were at the same weight and size. The frames of the beam trawls were 2.40 $\mathrm{m}$ in length and $40 \mathrm{~cm}$ in depth and were made of $50-\mathrm{mm}$ diameter pipes. The steel wires on the frames of the beam

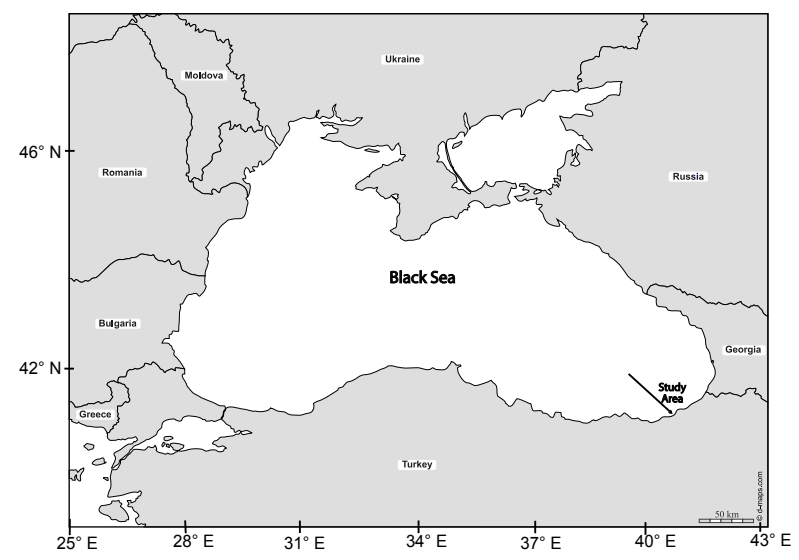

Fig. 1. The study area

trawls were $5 \mathrm{~mm}$ diameter and provide contact on the ground. Both ends of the steel wires were installed tautly to the feet $(5 \mathrm{~cm}$ depth and $0.5 \mathrm{~cm}$ thickness) which are called "nails" by the fishermen of the region (Fig. 2). The length of diamond-mesh commercial codend used during the study was $1 \mathrm{~m}$ and nominal mesh size was $72 \mathrm{~mm}$, as defined by Turkish Fisheries Regulations (Anonymous 2016a). The commercial codend was made of double $\mathrm{PE}$ twine and twine thickness was $2 \mathrm{~mm}$. In addition, the hanging ratio of the mesh was 0.50 in the codend. Apart from the codend, there was a chafer netting ( $5 \mathrm{~mm}$ twine thickness and 236 mesh in circumference) between steel wire and codend to strengthen the net. The square-mesh codend which was alternatively tested had same features as the diamond-mesh codend. However, the chafer netting that was used to strengthen the net is not common in the market, for this reason, chafer netting could not be used in square-mesh codend. In beam trawls, chains weighing $5 \mathrm{~kg}$ were used to facilitate the contact of the codend with the ground (Fig. 2). In addition to this, to increase the contact of the steel wire with the ground, two feet named "knives" (17 cm length and $1 \mathrm{~cm}$ thickness) were used. These feet force the steel wire from the top located in the middle of the frame to increase the contact with the ground (Fig. 2).

After the beam trawls were lifted aboard and the codends were emptied separately, the garbage, stone, and wood pieces were discarded. Afterwards, the catch was spread on the deck and jellyfish, crabs, and fish species were sorted out. The sub-sampling ratios for rapa whelk, bivalves, and other species were between $1 \div 1$ and $1 \div 36$. The samples of both beam trawls were separately put in bags and protected, to be subsequently measured in a laboratory. Samples taken to the laboratory were separated according to their species for counting and weighing. The total length of fish was measured using a fish scaling board. The veined rapa whelk, bivalves and crab species was measured by using $0.01 \mathrm{~mm}$ precision electronic calliper. The electronic calliper was calibrated after length measurements on samples taken for each

"Sağlam H., Düzgüneș E., Kutlu S., Dağtekin M., Başçınar S., Selen H., Șahin A. 2008. Deniz salyangozu avcılığında direçe alternatif farklı tuzak modellerinin geliștirilmesi. [Development of alternative different trap models in sea snail catching.] Su Ürünleri Merkez Araştırma Enstitüsü Müdürlüğü - Central Fisheries Research Institute, Trabzon, Turkey. [In Turkish.] 
haul. The length from spinal canal to apex was considered while measuring veined rapa whelk individuals. Maximum distance of anterior-posterior of bivalves and carapax length of crabs were taken into consideration in length measurements. Hermit crab species, which were obtained in excess could not be measured due to their unsuitable morphology.

The percentage catch reductions in square-mesh codend (SMC) compared to commercial diamond codend (CD) were calculated for the captured species. Paired $t$-tests were performed to judge whether the differences in catch amount for two codends were statistically significant. GLMM (Generalised Linear Mixed Models) was used to compare the length of obtained the veined rapa whelk and three by-catch species (Holst and Revill 2009). The proportion of the veined rapa whelk and three by-catch species retained at total length by 72 mm square-mesh codend (SMC) was calculated for each length as: $\mathrm{P}=\mathrm{SMC}$ count at length $\div$ (SMC and $\mathrm{CD}$ total count at length). The polynomial regression GLMM (with random intercepts) was used to fit curves for the expected proportions of the total catch retained by the $72 \mathrm{~mm}$ square-mesh codend (Holst and Revill 2009). The glmmPQL function in MASS package of the R statistical software, which uses a penalized quasi-likelihood approach, was used to fit the GLMM model (Holst and Revill 2009). The analyses proceeded by fitting the third order polynomials followed by subsequent reductions until all terms showed statistical significance $(P<0.05)$ based on the Wald's test, with the removal of one term at a time to determine the best-fit model as described by Holst and Revill (2009).

Short-term economic loss when changing from a commercial to square-mesh codend was estimated for the veined rapa whelk. The income was calculated for each codend by multiplying the weight of the veined rapa whelk by its price per $\mathrm{kg}$ at landing. The weights of the individuals retained in each size group which have a commercial value $(\geq 45 \mathrm{~mm})$ were calculated according to length-weight relation of the veined rapa whelk which determined by Sağlam et al. (unpublished*) for south- eastern Black Sea. Unit prices are values of the prices obtained from beam trawler operating for the study area. The price of target species varied according to its size (classified as small, medium, and big) and these size groups were taken into consideration for calculating the economic loss of square-mesh codend.

\section{RESULTS}

It was observed that there was a $77 \%$ reduction in the mean number of the captured individuals as by-catch in square-mesh codend (mean $=226$, standard error of the mean $(\mathrm{SE})=24.04)$ when compared with diamond-mesh codend $($ mean $=993, \mathrm{SE}=79.65)$, and this difference was found statistically significant $(P<0.05)$.

The total number of all species that were captured from diamond and square-mesh codend, the percentage reduction in square-mesh codend for each species and the results of paired $t$-test were given in Table 1. During the presently reported study, a total of 17 by-catch species was captured in both codends. The results showed that the catch amount of the 13 by-catch species decreased in squaremesh codend when compared with commercial codend. The amount of reduction for blood cockle (Anadara kagoshimensis); striped venus clam (Chamelea gallina); hermit crab (Diogenes pugilator); shore crab (Liocarcinus depurator); and Atlantic stargazer (Uranoscopus scaber) species were found to be statistically significant (Table 1).

GLMM (Generalised Linear Mixed Models) was performed for the veined rapa whelk (Rapana venosa), blood cockle (Anadara kagoshimensis), striped venus clam (Chamelea gallina), and shore crab (Liocarcinus depurator) species which were adequately captured in diamond and square-mesh codend.

Comparing to diamond-mesh codend, catch amount of the veined rapa whelk showed a 69-percentage-point reduction in square-mesh codend and this difference was found statistically significant (Table 1). Length-frequency distributions of the veined rapa whelk obtained by both codends (Fig. 3A) showed that square-mesh codend captured fewer individuals which were under the first maturity size (FMS) of $40 \mathrm{~mm}$ (Sağlam et al. 2009). Optimal polynomial

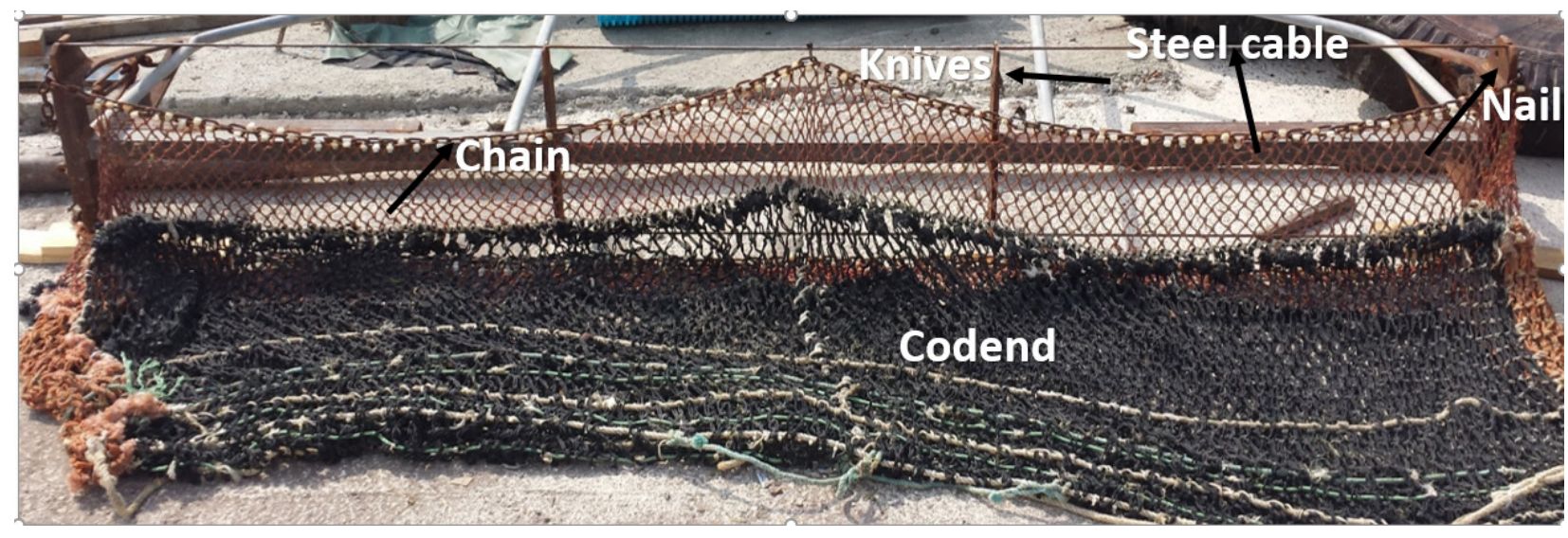

Fig. 2. Fishing gear used for the veined rapa whelk (Rapana venosa) fishery 
curve obtained by GLMM for this species was logit-linear model $(P<0.05)$ (Table 2$)$ and the results according to this model showed that square-mesh codend caught significantly fewer individuals at lengths below $55 \mathrm{~mm}$ (Fig. 3B). The total value of the $357 \mathrm{~kg}$ catch which has a commercial value for the veined rapa whelk obtained from commercial codend was 330 TRY (Turkish Lira) and when using the square-mesh codend (total commercial catch $=254 \mathrm{~kg}$ ), total income fell to 246 TRY, with a commercial loss of 25 percentage points.

Table 1

A comparison in the number of target (Rapana venosa) and by-catch bottom organisms captured using two types of codend, the commercial and the square-mesh

\begin{tabular}{|c|c|c|c|c|c|}
\hline \multirow{2}{*}{ Species } & \multirow{2}{*}{ Higher taxa } & \multicolumn{2}{|c|}{ No. of organisms caught } & \multirow{2}{*}{$\begin{array}{c}\text { Reduction } \\
\text { [percentage point] }\end{array}$} & \multirow{2}{*}{$P$-value } \\
\hline & & Commercial codend & Square-mesh codend & & \\
\hline Rapana venosa & MG & 41106 & 12911 & 68.59 & $<0.05$ \\
\hline Diogenes pugilator & $\mathrm{CD}$ & 9419 & 2108 & 77.62 & $<0.05$ \\
\hline Anadara kagoshimensis & MB & 2519 & 434 & 82.76 & $<0.05$ \\
\hline Tunicata gen. sp. & & 1465 & 551 & 62.42 & $>0.05$ \\
\hline Chamelea gallina & $\mathrm{MB}$ & 787 & 179 & 77.28 & $<0.05$ \\
\hline Donax trunculus & MB & 236 & 50 & 78.74 & $>0.05$ \\
\hline Tritia neritea & MG & 160 & 0 & 100.00 & \\
\hline Tritia reticulata & MG & 107 & 34 & 68.02 & $>0.05$ \\
\hline Liocarcinus depurator & $\mathrm{CD}$ & 98 & 6 & 93.88 & $<0.05$ \\
\hline Liocarcinus navigator & $\mathrm{CD}$ & 77 & 17 & 77.97 & $>0.05$ \\
\hline Uranoscopus scaber & $\mathrm{APe}$ & 12 & 2 & 83.33 & $<0.05$ \\
\hline Eriphia verrucosa & $\mathrm{CD}$ & 8 & 8 & 0.00 & $>0.05$ \\
\hline Arnoglossus kessleri & APl & 6 & 4 & 33.33 & $>0.05$ \\
\hline Solea $s p$ & APl & 4 & 4 & 0.00 & $>0.05$ \\
\hline Hippocampus sp. & ASy & 3 & 0 & 100.00 & \\
\hline Scorpaena porcus & $\mathrm{ASc}$ & 2 & 0 & 0.00 & \\
\hline Nereis sp. & $\mathrm{PP}$ & 0 & 2 & & \\
\hline
\end{tabular}

$P$-value $=P$-value of the paired t-test $P$-values in bold are significant; $\mathrm{MG}=$ Mollusca: Gastropoda, $\mathrm{CD}=\mathrm{Crustacea}:$ Decapoda, $\mathrm{MB}=$ Mollusca: Bivalvia, APe = Actinopterygii: Perciformes, APl Actinopterygii: Pleuronectiformes, ASy = Actinopterygii: Syngnathiformes, $\mathrm{ASc}=$ Actinopterygii: Scorpaeniformes, $\mathrm{PP}=$ Polychaeta: Phyllodocida .

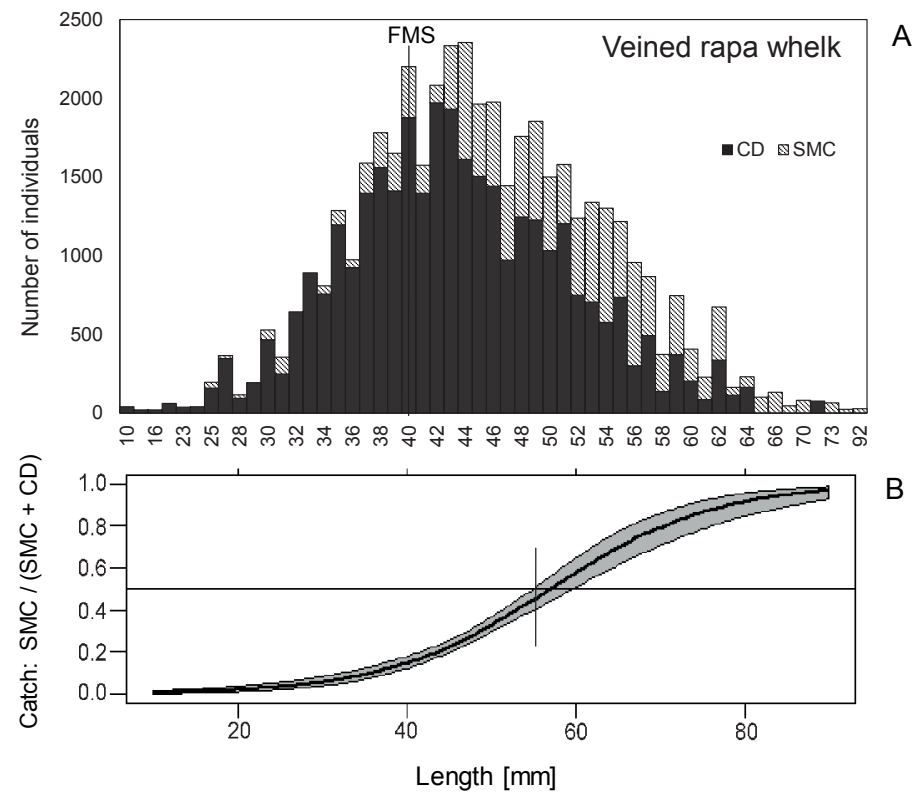

Fig. 3. (A) Length-frequency distributions of the veined rapa whelk, Rapana venosa, with first maturity size; FMS = first maturity size (vertical line); (B) GLMM modelling of size of the veined rapa whelk, showing differences in catch at length; catch ratio of 0.5 (horizontal line) indicates both codends catching equal numbers of organisms; the solid line represents the mean, grey band represents the $95 \%$ confidence level; vertical line shows the length under which the reduction of catch is significant; $\mathrm{SMC}=$ square-mesh codend, $\mathrm{CD}=$ commercial codend 
It was determined that there is a significant difference between diamond and square-mesh codend in the catch amount of blood cockle (Table 1). When examining the length-frequency distributions in Fig. 4A, it was observed that square-mesh codend caught fewer individuals under the length at first maturity of $20 \mathrm{~mm}$ (SSahin et al. 2006) and this reduction was significantly length-related for blood cockle as it was revealed by logit-linear model $(P<$ 0.05) (Table 2) obtained by GLMM (Fig. 4B).

Comparing to diamond-mesh codend, catch amount of striped venus clam showed a $77 \%$ reduction in squaremesh codend and this difference between two codends was found statistically significant $(P<0.05)$. Minimum landing size (MLS) defined by the Turkish Fisheries Regulations (TFR) for striped venus clam is $17 \mathrm{~mm}$ (Anonymous 2016a) and it was seen that all of striped venus clam individuals obtained by both codends were under the MLS (Fig. 5A). Although there was a reduction in striped venus clam across lengths, the reduction was not significantly length-related as tested by GLMM $(P>$ 0.05 , Fig. 5B).

It was determined that there was a significant difference between diamond and square-mesh codend in the catch amount of shore crab (Table 1). Length-frequency distributions of shore crab captured in both codends (Fig. 6A) showed that square-mesh codend captured fewer individuals which are under the first maturity size (FMS) (26 mm for females, Muiño et al. 1999). Although there was a reduction in shore crab across lengths, the reduction was not significantly length-related according to $\operatorname{GLMM}(P>0.05$, Fig. 6B).

\section{DISCUSSION}

In this study, square-mesh codend tested as an alternative to commercial diamond-mesh codend considerably reduced the by-catch amount but, the veined rapa whelk amount fell by half. This finding is in agreement with the findings of Fonteyne and Polet (2002) that showed square-mesh windows inserted in the belly significantly reduced the by-catch of most benthic species in the flatfish beam trawl fisheries but some loss of the commercial catch had been reported.

Results showed that the veined rapa whelk individuals over the length at first maturity could easily escape from square-mesh codend. Nevertheless, the individuals under $55 \mathrm{~mm}$ were successful at escaping. Due to individuals which are over $45 \mathrm{~mm}$ and have a commercial value in study field, this situation causes a $25 \%$ decline in fishermen profit.

When we compared the square-mesh codend against the diamond-mesh codend, it was evident that the squaremesh codend considerably reduced the by-catch amount of blood cockle and caught by 75 percentage points fewer individuals which are under the length at first spawning. However, $87 \%$ of 434 individuals caught with squaremesh codend in a total of 15 hauls were under the length at the first maturity. This situation can be explained by the veined rapa whelk individuals. They clog mesh openings after a period during the haul and block small benthic animals from escaping (Sağlam et al. unpublished*). The underwater observations carried out by the veined rapa whelk beam trawl fisheries to examine the behaviour of by-catch species showed that small benthic individuals lifted up by the steel wire were displaced toward the codend (Eryaşar 2018). With low amount of the veined rapa whelk at the beginning of haul, juveniles of bivalves can escape easily from the meshes. When the veined rapa whelk individuals accumulated and covered the meshes, this led to a decrease in the escape chance and also caused juveniles to stick to the veined rapa whelk individuals. A similar situation was observed in striped venus clam species. Although there was a significant decrease in by-catch amount in square-mesh codend, all individuals caught by this codend were under the minimum landing size. This situation may be explained by the presence of small individuals which are found closer to the bottom surface compared with larger ones (Gaspar and Chícharo 2007). In addition of these, it should be noted that the rate

Table 2

Coefficient values and significance $(P)$ based on Generalized Linear Mixed Modelling (GLMM) for selected species - veined rapa whelk (Rapana venosa), blood cockle (Anadara kagoshimensis), striped venus clam (Chamelea gallina), and shore crab (Liocarcinus depurator)

\begin{tabular}{llcccccc}
\hline \multicolumn{1}{c}{ Species } & \multicolumn{2}{c}{ Coefficient } & Value & SE & df & $t$-value & $P$-value \\
\hline \multirow{2}{*}{ Rapana venosa } & \multirow{2}{*}{ Linear } & $\beta 0$ & -5.844724 & 0.4998185 & 51 & -11.6937 & $<\mathbf{0 . 0 5}$ \\
& & $\beta 1$ & 0.102632 & 0.0102874 & 51 & 9.976477 & $<\mathbf{0 . 0 5}$ \\
Anadara kagoshimensis & Linear & $\beta 0$ & -0.8023481 & 0.381034 & 34 & -2.10571 & $<\mathbf{0 . 0 5}$ \\
Chamelea gallina & Constant & $\beta 1$ & -0.0790543 & 0.0310411 & 34 & -2.54676 & $<\mathbf{0 . 0 5}$ \\
& Linear & $\beta 0$ & -1.481844 & 0.3084331 & 5 & -4.80442 & $<\mathbf{0 . 0 5}$ \\
& & $\beta 1$ & -1.3234909 & 2.3502181 & 4 & -0.56314 & $>0.05$ \\
Liocarcinus depurator & Constant & $\beta 0$ & -2.74084 & 0.3844151 & 17 & -7.1299 & $<0.05$ \\
& Linear & $\beta 0$ & -4.21456 & 2.217351 & 16 & -1.90072 & $>0.05$ \\
& & $\beta 1$ & 0.055097 & 0.0801869 & 16 & 0.687103 & $>0.05$ \\
\hline
\end{tabular}

The logit-linear is found as the best model for rapa whelk and blood cockle; the logit-constant is found as the best model for striped venus clam and shore crab; $\mathrm{SE}=$ standard error, $\mathrm{df}=$ degree of freedom; $P$-values in bold are significant. 

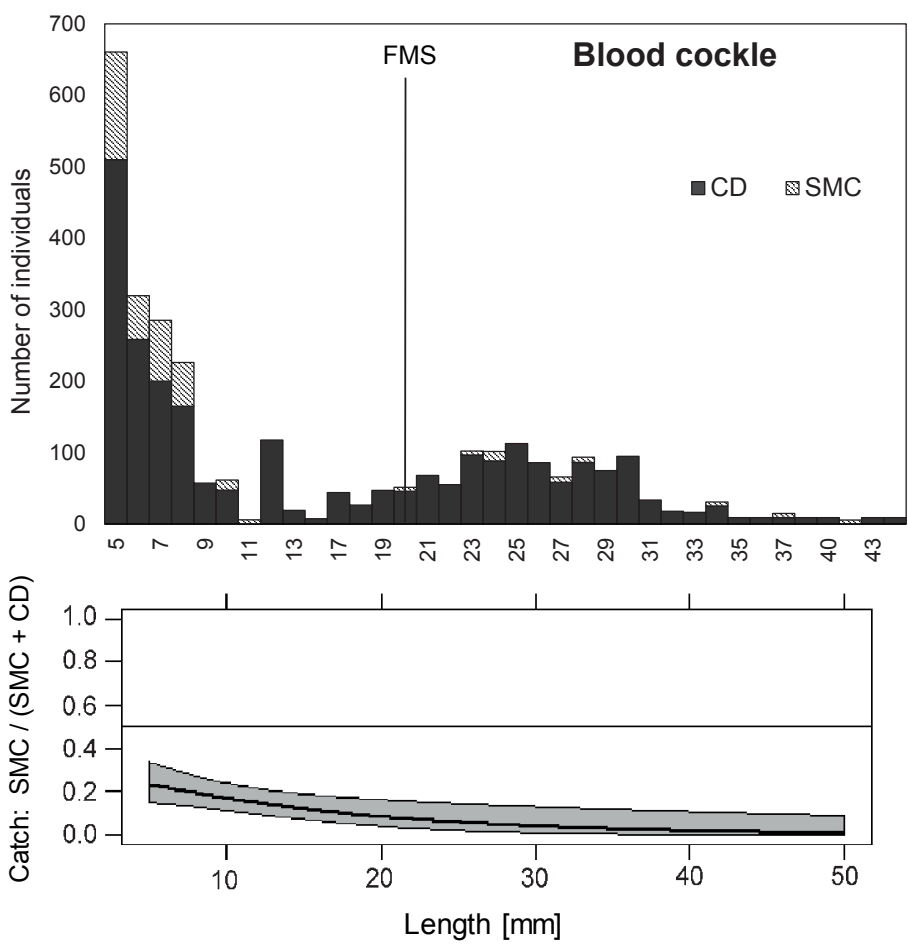

A

B

Fig. 4. (A) Length-frequency distributions of blood cockle, Anadara kagoshimensis, with first maturity size; FMS = first maturity size (vertical line); (B) GLMM modelling of size of blood cockle, showing differences in catch at length; catch ratio of 0.5 (horizontal line) indicates both codends catching equal numbers of organisms; the solid line represents the mean, grey band represents the $95 \%$ confidence level; SMC = square-mesh codend, $\mathrm{CD}=$ commercial codend

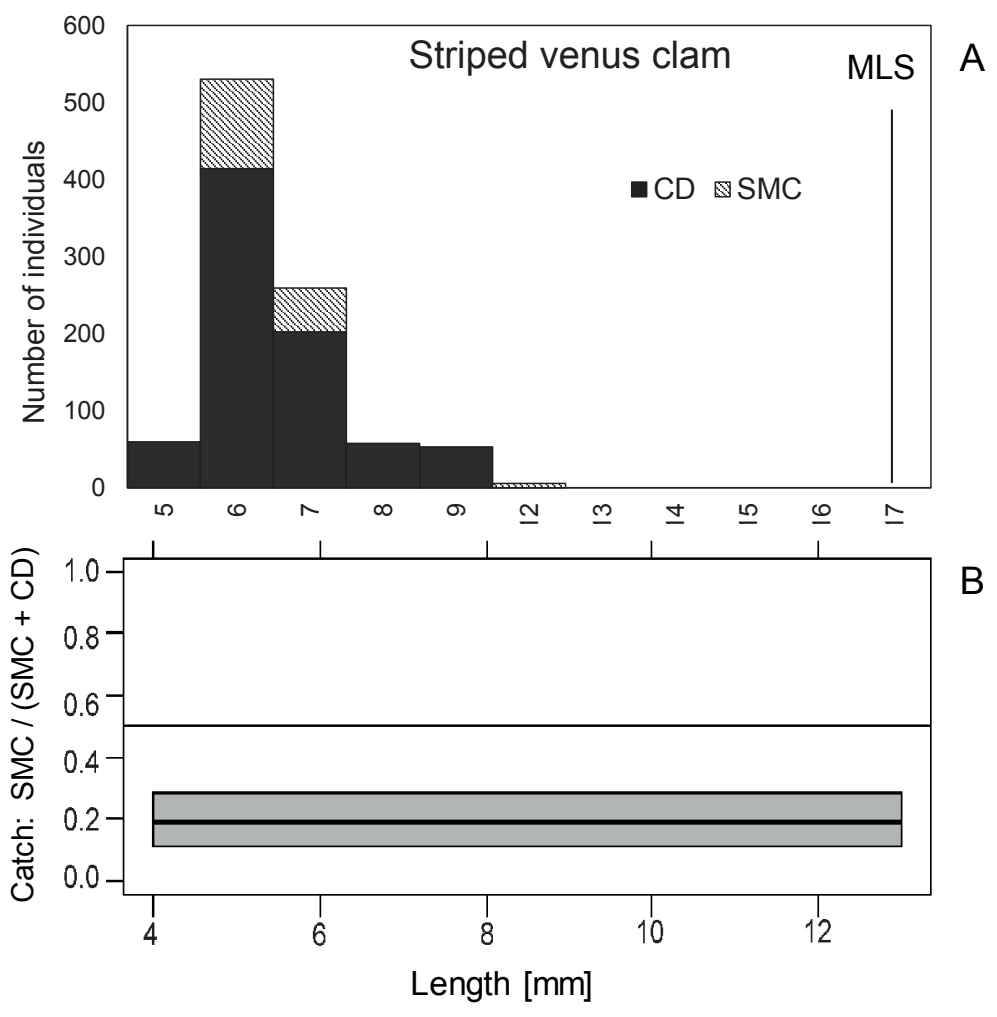

Fig. 5. (A) Length-frequency distributions of striped venus clam, Chamelea gallina, with minimum landing size (MLS) (vertical line); (B) GLMM modelling of size of striped venus clam, showing differences in catch at length; catch ratio of 0.5 (horizontal line) indicates both codends catching equal numbers of organisms; the solid line represents the mean, grey band represents the $95 \%$ confidence level; $\mathrm{SMC}=$ square-mesh codend, $\mathrm{CD}=$ commercial codend 

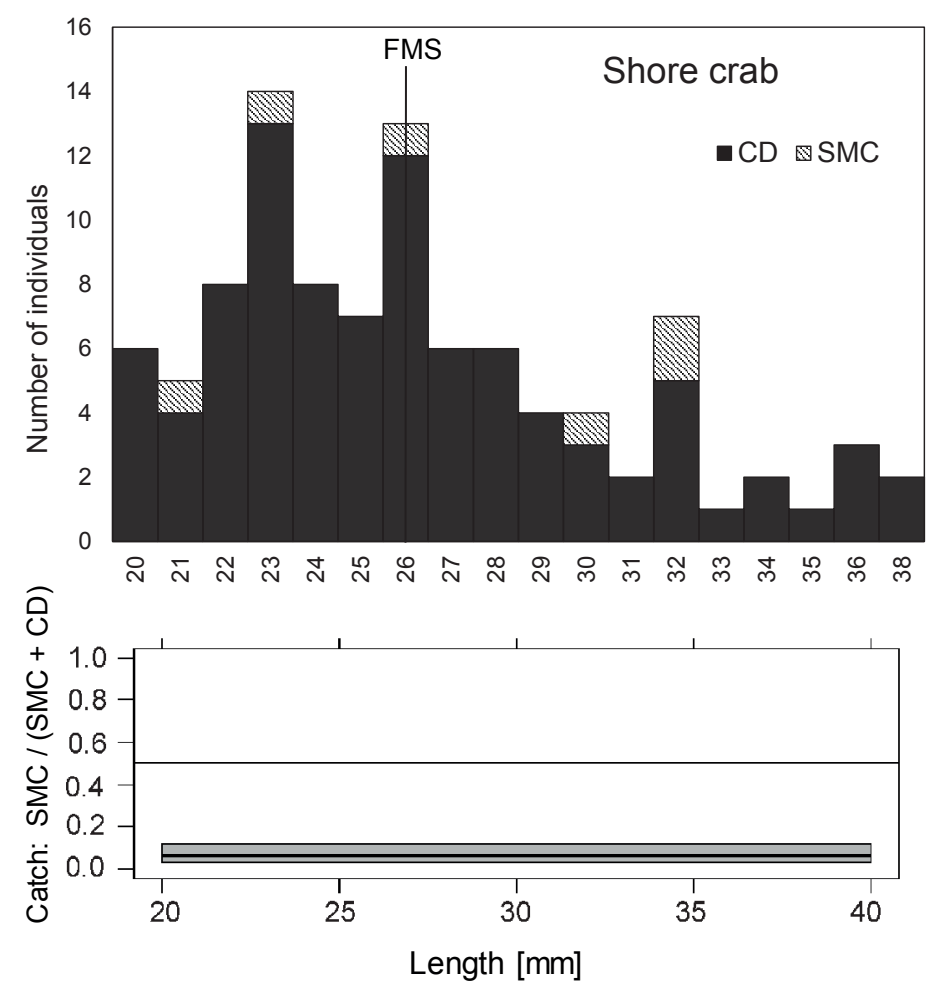

Fig. 6. (A) Length-frequency distributions of shore crab, Liocarcinus depurator, with first maturity size; FMS = first maturity size (vertical line); (B) GLMM modelling of size of shore crab, showing differences in catch at length; catch ratio of 0.5 (horizontal line) indicates both codends catching equal numbers of organisms; the solid line represents the mean, grey band represents the 95\% confidence level; SMC = square-mesh codend, $\mathrm{CD}=$ commercial codend

of releasing small benthic animals in the square-mesh codend might decrease in cases where the total catch amount is high. This situation was observed a few hauls during this study and can be explained by a situation of clogging of mesh openings mentioned above.

The square-mesh codend used in this study has been found successful in the reduction of the by-catch of small crabs like shore crab. This situation can be explained by the morphological structure of shore crab which makes it easier to escape from square-mesh codend when compared with commercial diamond-mesh codend. However, the situation mentioned above is different for huge species like warty crab (Eriphia verrucosa). It can be seen that the mesh of square-mesh codend used in this study is not enough for large species like warty crab to escape. On the other hand, the observations carried out on the board have shown that the majority of warty crab individuals caught by both codends were alive and their conditions were good.

The studies carried out to increase the selectivity of bottom trawl net in the Mediterranean Sea showed that comparing to diamond-mesh codend, square-mesh codend, or panels give more chance individuals that have round shaped body to escape (Sala et al. 2008, Eryaşar and Özbilgin 2015, Özbilgin et al. 2015). The same situation has been observed in Atlantic stargazer species that has round-shaped body form for this study and this codend was found successful for Atlantic stargazer species to escape.

The square-mesh codend has been found insufficient for escaping the flatfish species (Solea sp. and Arnoglossus kessleri). Considering the body form of flatfishes caught in this study, it is understood that square-mesh codends are not proper for flatfish species to escape. Similar findings for square-mesh codends had been reported in the studies that were carried out in the Mediterranean Sea about bottom trawl net selectivity (Özbilgin et al. 2012, Özbilgin et al. 2015, Eryaşar 2017). Özbilgin et al. (2012) reported that square-mesh codend is not a definitive solution to the poor bottom trawl net selection, especially for many flat and high-bodied fish species.

In this study, chafer netting could not be used in the square-mesh codend due to its absence on the market. Although these attachments are used to prevent the codend from wear and/or tears, results showed that they block the mesh and therefore retain fish individuals caught in the net (Flewwelling 1999). A similar situation can be observed for small benthic species. Therefore, it should be taken into account that if chafer netting was used in the square-mesh codend for this study, it would have effected the escape rate of small gastropods and bivalves.

Consequently, the square-mesh codend was found successful in decreasing the by-catch amount of many benthic species except for flatfish species and large crabs. In addition to this, the veined rapa whelk amount fell by half. This means a 25-percentage-point profit decrease for fishermen. Future studies are needed to find a way to decrease the loss of target species. It will be helpful to analyse the effect of square-mesh panels on benthic by-catch and the potential loss of product caused by it. For this purpose, behaviour 
observations of by-catch species in codend of the beam trawl should be done in detail and square-mesh panels can be put in appropriate places of the codend with the results to be obtained from behaviour observations.

\section{ACKNOWLEDGEMENTS}

I would like to thank the captains and crews of the FV Piryoz 53. Thanks are also extended to Dr Göktuğ Dalgıç and Yusuf Ceylan for their help in the sea trials. This study was financed by the Recep Tayyip Erdogan University Research Project Fund (Project No: FBA2017-781).

\section{REFERENCES}

Altınağaç U., Ayaz A., Kara A. 2004. Farklı Boyutlardaki Çemberli Kaldırma Ağları ile Deniz Salyangozu (Rapana venosa (Valenciennes, 1846)) Avc1lığ1 Üzerine Bir Ön Çalışma. [A preliminary study on the whelk fisheries (Rapana venosa (Valenciennes, 1846)) using liftnets of various sizes.] E.Ü. Su Ürünleri Dergisi - Ege Journal of Fisheries and Aquatic Sciences 21 (3-4): 295-299. [In Turkish.]

Anonymous 2016a. Ticari amaçlı su ürünleri avcılığının düzenlenmesi hakkında tebliğ (No: 2016/35). [The commercial fish catching regulations circular (No. 2016/35).] Gıda, Tarım ve Hayvancılık Bakanlığı. [Ministry of Food, Agriculture and Livestock.] Ankara, Turkey. [In Turkish.]

Anonymous. 2016b. The state of Mediterranean and Black Sea fisheries. General Fisheries Commission for the Mediterranean. FAO, Rome.

Anonymous 2016c. Su Ürünleri İstatistikleri. [Fishery statistics 2016.] Türkstat. [Turkish Statistical Institute.] Ankara, Turkey. [In Turkish.]

Ateş C., Deval M.C., Bök T., Tosunoğlu Z. 2010. Selectivity of diamond (PA) and square (PE) mesh codends for commercially important fish species in the Antalya Bay, eastern Mediterranean. Journal of Applied Ichthyology 26 (3): 465-471. DOI: 10.1111/j.1439-0426.2010.01462.x

Bilecik N. 1990. Karadeniz'in Türkiye kıyılarında deniz salyangozu (Rapana venosa (V.))'un dağılımı ve Karadeniz balıkçılığı üzerine olan etkisi. [Distribution of sea snail (Rapana venosa (V.)) in the Turkish coast of Black Sea and its impact on Black Sea fisheries.] Bodrum Su Ürünleri Araştırma Enstitüsü Yayınları Bodrum Fisheries Research Institute Publications No. 1. Seri B. Bodrum, Turkey [In Turkish.]

Eryaşar A.R. 2017. Kuzeydoğu Akdeniz'de kupes (Boops boops) ve dil balığı (Solea solea) için ticari ve alternatif torbaların seçiciliği. [Selectivity of commercial and alternative codends for bogue (Boops boops) and common sole (Solea solea) in northeastern Mediterranean.] Su Ürünleri Dergisi - Ege Journal of Fisheries and Aquatic Sciences 34 (1): 57-62. [In Turkish.] DOI: 10.12714/egejfas.2017.34.1.08

Eryasar A.R., Ceylan Y., Dalgic G., Yesilcicek T. 2018. By-catch in the commercial beam trawl fishery for rapa whelk in the Black Sea. Mediterranean Marine Science 19 (1): 69-78. DOI: 10.12681/mms. 13873

Eryaşar A.R., Özbilgin H. 2015. Implications for catch composition and revenue in changing from diamond to square mesh codends in the northeastern Mediterranean. Journal of Applied Ichthyology 31 (2): 282-289. DOI: 10.1111/jai.12643

Flewwelling P. 1995. An introduction to monitoring, control and surveillance for capture fisheries. FAO Fisheries Technical Paper No. 338. FAO, Rome.

Fonteyne R., Polet H. 2002. Reducing the benthos bycatch in flatfish beam trawling by means of technical modifications. Fisheries Research 55 (1-3): 219-230. DOI: $10.1016 / \mathrm{S} 0165-7836(01) 00287-9$

Gaspar M.B., Chícharo L.M. 2007. [5] Modifying dredges to reduce by-catch and impacts on the benthos. Pp. 95-140. In: Kennelly S.J. (ed.) By-catch reduction in the world's fisheries. Springer, Dordrecht, the Netherlands. DOI: 10.1007/978-1-4020-6078-6

Hall M.A., Alverson D.L., Metuzals K.I. 2000. Bycatch: Problems and solutions. Marine Pollution Bulletin 41 (1-6): 204-219. DOI: 10.1016/S0025326X(00)00111-9

Holst R., Revill A. 2009. A simple statistical method for catch comparison studies. Fisheries Research 95 (2-3): 254-259. DOI: 10.1016/j.fishres.2008.09.027

KaykaçM.H.,Zengin M.,Özcan-Akpınarİ.,TosunoğluZ. 2014. Samsun (Karadeniz) kıyılarında kullanılan sürükleme av araçlarının yapısal özellikleri. [Structural characteristics of towed fishing gears used in the Samsun coast (Black Sea).] Su Ürünleri Dergisi - Ege Journal of Fisheries and Aquatic Sciences 31 (2): $87-$ 96 [In Turkish.] DOI: 10.12714/egejfas.2014.31.2.05

Kelleher K. 2005. Discards in the world's marine fisheries. An update. FAO Fisheries Technical Paper No. 470, FAO, Rome.

Kideys A.E., Karayucel S., Bat L., Sahin F., Erik G., Erdem E., Aksu H. 2007. A new method for the invasive whelk (Rapana Venosa) fishery in the Black Sea. Rapports et procés-verbaux des réunions Commission internationale pour l'exploration scientifique de la Mer Méditerranée 38: 519

Konsulova T., Todorova V., Konsulov A. 2001. Investigations on the effect of ecological method for protection against illegal bottom trawling in the Black Sea-Preliminary results. Rapports et procés-verbaux des réunions Commission internationale pour l'exploration scientifique de la Mer Méditerranée 36: 287.

Muiño R., Fernández L., González-Gurriarán E., Freire J., Vilar J.A. 1999. Size at maturity of Liocarcinus depurator (Brachyura: Portunidae): A reproductive and morphometric study. Journal of the Marine Biological Association of the United Kingdom 79 (2): 295-303. DOI: 10.1017/S0025315498000320

Özbilgin H., Eryaşar A.R., Gökçe G., Doğanyılmaz Özbilgin Y., Bozaoğlu A.S., Kalecik E., Herrmann B. 2015. Size selectivity of hand and machine woven codends and short term commercial loss in the 
northeastern Mediterranean. Fisheries Research 164: 73-85. DOI: 10.1016/j.fishres.2014.10.022

Özbilgin H., Tokaç A., Kaykaç H. 2012. Selectivity of commercial compared to larger mesh and square mesh trawl codends for four fish species in the Aegean Sea. Journal of Applied Ichthyology 28 (1): 51-59. DOI: 10.1111/j.1439-0426.2011.01916.x

Robertson J.H.B., Stewart P.A.M. 1988. A comparison of size selection of haddock and whiting by square and diamond mesh codends. ICES Journal of Marine Science 44 (2): 148-161. DOI: 10.1093/ icesjms/44.2.148

Sağlam H., Düzgüneş E., Öğüt H. 2009. Reproductive ecology of the invasive whelk Rapana venosa Valenciennes, 1846, in the southeastern Black Sea (Gastropoda: Muricidae). ICES Journal of Marine Science 66 (9): 1865-1867. DOI: 10.1093/icesjms/ fsp184

Sağlam N.E., Kesici U.Y., Akdoğan P. 2011. Karadeniz'deki bazı istilacı türler ve Karadeniz ekosistemi üzerine olan etkileri. [Some invasive species in the Black Sea and their effects on the Black Sea ecosystem.] Eğirdir Su Ürünleri Fakültesi Dergisi
- Journal of Egirdir Fisheries Faculty 7 (1): 25-38. [In Turkish.]

Sala A., Lucchetti A., Piccinetti C., Ferretti M. 2008. Size selection by diamond and square mesh codends in multi species Mediterranean demersal trawl fisheries. Fisheries Research 93 (1-2): 8-21. DOI: 10.1016/j. fishres.2008.02.003

Şahin C., Düzgüneş E., Okumuş İ. 2006. Seasonal variations in condition index and gonadal development of the introduced blood cockle Anadara inaequivalvis (Bruguiere, 1789) in the southeastern Black Sea coast. Turkish Journal of Fisheries and Aquatic Sciences 6 (2): 155-163.

Tokaç A., Özbilgin H., Kaykaç H. 2010. Selectivity of conventional and alternative codend design for five fish species in the Aegean Sea. Journal of Applied Ichthyology 26 (3): 403-409. DOI: 10.1111/j.14390426.2009.01379.x

Tsagarakis K., Palialexis A., Vassilopoulou V. 2014. Mediterranean fishery discards: Review of the existing knowledge. ICES Journal of Marine Science 71 (5): 1219-1234. DOI: 10.1093/icesjms/fst074

Received: 8 December 2017

Accepted: 23 June 2018

Published electronically: 30 June 2018 
